\title{
Field growth and rubber yield of in vitro micropropagated plants of clones PR 107, IRCA 18 and RRIM 600 of Hevea brasiliensis (Muëll.-Arg.)
}

\author{
${ }^{1,2}$ Dibi, K., ${ }^{2}$ Boko, C., ${ }^{2}$ Obouayeba, S., ${ }^{2}$ Gnagne, M., ${ }^{2}$ Dea G.B., ${ }^{3}$ Carron, M.P. and ${ }^{1}$ Anno, \\ A.P. \\ ${ }^{1}$ Laboratory of Plant Physiology, UFR Biosciences, University of Cocody-Abidjan, Côte \\ d'Ivoire, 22 BP 582 Abidjan 22, Côte d'Ivoire ; \\ ${ }^{2}$ Rubber Program, Bimbresso Research Station, National Center for Agronomic Research \\ (CNRA), Côte d'Ivoire, 01 BP 1740 Abidjan 01, Côte d'Ivoire; \\ ${ }^{3}$ Rubber Program, International Cooperation Center of Agronomic Research for Development \\ (CIRAD) France.
}

\begin{abstract}
Rubber cultivation has been handicapped from the outset by the impossibility of obtaining selfrooted clones or rootstock clones. The grafting of clonal buds on not selected rootstock remains at the present time the only method of propagation available for the establishment of plantations. However, this "semi-vegetative" multiplication leads to certain heterogeneity and a reduction in the production of rubber compared to that of the mother tree selected. Fields trials have been conducted in Côte d'Ivoire to assess the relative gain in strength and in rubber production due to the use of self rooted in vitro plantlets of rubber on farm in comparison with conventional mature budded clones. Experimentation was made with trees of clones PR 107, IRCA 18 and RIIM 600 obtained by somatic embryogenesis or microcutting. The results showed a gain in volume of the trunk from $9.93 \%$ to $16.83 \%$ due to the use of in vitro plantlets. A gain of dry rubber production per tree of $3.5 \%$ to $32.35 \%$ has also been recorded. The gain in girth and rubber production of in vitro plantlets has been influenced by the metabolic class and the physiological profile of the clone. In light of these results, the use of in vitro plantlet as planting material could be considered to increase the productivity of rubber plantations.
\end{abstract}

Keywords: Hevea brasiliensis, in vitro plantlet, budded plant, growth, rubber yield

\section{INTRODUCTION}

In rubber tree cultivation, the yield of field depends on the quality of trees. Those trees must have high yield potentialities and be as homogenous as possible (Combe and Du Plessix, 1971). The first rubber exploitations were set up in Southeast Asia from 1890 to 1930 , often using seed of uncontrolled origin. The heterogeneity of this planting material and the difficulty of obtaining large quantities of seed of known origin inspired a searching of vegetative propagating elite trees. The impossibility of obtaining cuttings from selected mature trees led to the widespread of grafting practice onto seedlings. Therefore it is budding onto rootstocks obtained from non-selected seed and genetically heterogeneous, that is still used today to set up clonal farms. This "semi-vegetative" propagation technique had some drawbacks, which warranted continuous research to develop a "complete vegetative" propagation method, first by cuttings and then, from the 1970s onwards, by in vitro culture. The best seedlings grow much better and produce much more rubber than grafted clones (Dijkman, 1951). Some of the difference in performance can be due to the genetic heterogeneity of the rootstock and the maturity of the clonal material which are buds from adult branches maintained during several decades in "budwood gardens" (Carron et al., 1989). Vegetative propagation of selected genotypes has come up against difficulties in reproducing a root system comparable to that formed by plants grown from seeds (Carron and Enjalric, 1983). Vegetative propagation by in vitro culture should probably solve these problems. Since 1979, CIRAD(1) embarked upon two research topics, microcuttings and somatic embryogenesis of rubber tree (Carron, 1982). Many in vitro plantlets were then produced from seedlings and selected clones. Field comparative trials were set 
up from 1989 onwards at Bimbresso experimental field of CNRA(2), in Côte d'Ivoire (Carron et al. 1997; Dibi, 2004).

Generally speaking, the published results concern only the first years of growth and production. As a result, these data do not provide unequivocal conclusions as to the advantages of in vitro propagation.

The purpose of this work is to contribute to the increase of productivity in rubber cultivation by the use of in vitro plantlets. This study particularly intends to estimate the relative gain in strength and in rubber production due to the use of in vitro plantlets of rubber on farm. Three rubber genotypes are concerned: PR 107, IRCA 18 and RRIM 600.

\section{MATERIALS AND METHODS}

The study site: This study was conducted in Côte d'Ivoire at the CNRA research station of Bimbresso. The site has typical traits of the humid subtropical guinea forest climate type. The annual temperature mean is $27^{\circ} \mathrm{C}$ and rainfall is abundant, $1821 \mathrm{~mm}$ in 1994 spread over 100 days. The soils are very deep, uniform, with a loamy sand texture (50\% coarse sands, $24 \%$ fine sands, $22 \%$ clays). They derived from a complete alteration process of the primary minerals. They have good physical qualities throughout the profile (porosity/texture/structure), with few or no obstacles to penetration. The $0-60 \mathrm{~cm}$ horizon is reveals the nutritional condition of the trees, since it contains the majority of mineral and organic nutrients. Therefore this environment presents few constraints and enables rubber trees to express their morphogenetic potentials (Le Roux, 1994).

Plant material: The plants used in this experiment were consisted of three clones of Hevea brasiliensis, PR 107, RRIM 600 and IRCA 18 which have respectively a slow, medium and high metabolism (Anonymous 2, 1993). Each clone was represented by two propagation modes which are grafted plant or as in vitro plantlets. Grafted or budded plants were obtained by the grafting of clonal bud from the budwood garden of CNRA, onto rootstocks obtained from seedling of 7 to 8 month old. The plants obtained by in vitro culture were produced in France by microcuttings for RRIM 600 and IRCA 18 (Lardet et al., 1994), or by somatic embryogenesis for PR 107 (Carron et al., 1998). They were sent in tubes to the CNRA research station (Côte d'Ivoire), where acclimatization and field transfer operations were carried out. For PR 107, the plants were acclimatized in the CIRAD greenhouses in Montpellier and then sent to Côte d'Ivoire a month before planting.

Experiment design and layout: The study was conducted in three experimental plots (one for each clone) in a randomized complete block design with one factor: the propagation mode. The two treatments are the in vitro plantlet $(\mathrm{V})$ and the budded plant $(\mathrm{G})$. The planting density was 510 trees $(7 \times 2.8$ $\mathrm{m})$. The plot of PR 107 has 6 repetitions with 11 plants per treatment for each replicated block. The plot of RRIM 600 involved three repetitions with 15 trees per treatment per block. The plot of IRCA 18 involved three repetitions with 30 trees per treatment per block.

For each clone the in vitro plantlet treatment was compared to the budded plants used as a control. The culture was conducted according to the usual management and fertilization applied in rubber cultivation in Côte d'Ivoire.

The plots have been tapped at 6 years old when $50 \%$ of the trees presented a trunk circumference greater than or equal to $50 \mathrm{~cm}$ at $1 \mathrm{~m}$ above the ground. The tapping system used is the half spiral cut tapped downward at fourth daily frequency six days in tapping followed by one day rest $(1 / 2 \mathrm{~s} d / 46 \mathrm{~d} / 7)$. Hence trees are tapped or 6 times per month. They were also stimulated with ethephon mixed with palm oil at a concentration of $2.5 \%$ active ingredient. At each application, $1 \mathrm{~g}$ of stimulant is applied on panel on $1 \mathrm{~cm}$ band. The stimulation frequencies were 10, 8 and 4 times per year respectively for the PR 107, RRIM 600 and IRCA 18.

\section{Data recorded}

Radial vegetative growth: Observations were led in experimental plots to count diseased trees, dead or stunted.

In order to estimate the radial growth, the tree trunk circumference was measured using a tape measure. The measurements are performed every six months to three height levels previously marked with paint (50 cm, $1 \mathrm{~m}$ and $1.70 \mathrm{~m}$ above ground). The relative increase of the trunk at $1 \mathrm{~m}$ above the ground and the volume of the portion of the trunk between 0.25 and $1.70 \mathrm{~m}$ of soil were calculated to estimate the gain in biomass.

Rubber production: A production check on each tree was made every 4 weeks. A sample of the rubber yielded was used to determine the coefficient of transformation of each treatment, which permits 
determination of the weight in dry rubber. The production was expressed in gram per tree $(\mathrm{g} / \mathrm{t})$ and in kilogram per hectare $(\mathrm{kg} / \mathrm{ha})$.

Latex analysis: A latex microdiagnosis was carried out once a year between August and January taking into account the dry rubber rate and the sucrose, inorganic phosphorus and thiol contents. To determine the dry rate (\%), a latex sample was weighed before and after drying in oven at $80^{\circ} \mathrm{C}$ for $24 \mathrm{~h}$. The sucrose, the inorganic phosphorus and the reduced thiol groupings were measured on the clear serum called TCA-serum (trichloroacetic acid) that is obtained after latex acid coagulation, respectively, by the Ashwell anthrone method (1957), the Taussky and Shorr molybdate ammonium method (1953) and the Boyne and Ellman acid dinitro-dithio-dibenzoic (DTNB) method (1972). The results are stated in mmole per litre of latex $(\mathrm{mM} / \mathrm{l})$.

Data analysis: Rubber production, plant growth, sanitary state and the latex analysis data were subjected to statistical analysis. Analysis of variance, modeling of binomial proportions (Pearson chisquare) and the development of basic statistics were performed using the software GenStat Discovery Edition 3. The level of significance of differences between means was estimated using the LSD (Low
Significant Difference) for a probability threshold of $5 \%$.

\section{RESULTS AND DISCUSSIONS}

\section{RESULTS}

Table 1 shows that the in vitro plantlets of clone PR 107 recorded significantly least losses (13,3 PC.) compared to grafted plants. The existence of hearths of Fomes in blocks of in vitro plantlets of plots of RRIM 600 and IRCA 18 has resulted to higher losses. However this superiority of the losses of the in vitro plantlets was significant only in plot of IRCA 18. In short, the rate of useful plants (making), after elimination of losses (dead plants, broken, stunted) of the in vitro plantlets compared to grafted plants, was statistically higher for the plot of PR 107, identical for RRIM 600, weaker for IRCA 18 (Table 1).

Radial vegetative growth: Concerning the clone PR 107 , the trunk girth at $1 \mathrm{~m}$ above the ground and the volume of the trunk were statistically identical for both in vitro plantlets and budded plants, and for all years of evaluation (Figure 1 and Table 2). However, in vitro plantlets recorded relatively to budded plants a gain of volume of $9.93 \%$ (Table 2 ).

Table 1: State of population of trees observed in experimental plots

\begin{tabular}{|c|c|c|c|c|c|c|c|c|c|c|c|}
\hline \multirow{3}{*}{ Clones } & \multirow{3}{*}{ Treatment } & \multirow{3}{*}{$\begin{array}{c}\text { Total } \\
\text { planted }\end{array}$} & \multicolumn{7}{|c|}{ unusable trees } & \multirow{2}{*}{\multicolumn{2}{|c|}{$\begin{array}{c}\text { usable } \\
\text { Trees }\end{array}$}} \\
\hline & & & dead & dead & stunted & broken & other & \multicolumn{2}{|c|}{ Total losses } & & \\
\hline & & & & & & & & nb & $\%$ & nb & $\%$ \\
\hline \multirow{2}{*}{ PR 107} & $\mathrm{~V}$ & 66 & 0 & $0 \mathrm{a}$ & $2 a$ & $0 \mathrm{a}$ & 11 & 13 & 19,7 & $53 a$ & 80,3 \\
\hline & G & 66 & 0 & $3 a$ & $4 a$ & $0 \mathrm{a}$ & 13 & 20 & 30,3 & $46 \mathrm{~b}$ & 69,7 \\
\hline \multirow{2}{*}{ RRIM 600} & V & 45 & 4 & $1 \mathrm{a}$ & $0 \mathrm{a}$ & $0 \mathrm{a}$ & 3 & 8 & 17,8 & $37 \mathrm{a}$ & 82,2 \\
\hline & G & 45 & 0 & $2 a$ & $0 \mathrm{a}$ & $1 a$ & 0 & 3 & 6,7 & $42 \mathrm{a}$ & 93,3 \\
\hline \multirow{2}{*}{ IRCA 18} & $\mathrm{~V}$ & 89 & 2 & $6 a$ & $2 a$ & $3 a$ & 9 & 22 & 24,7 & $67 \mathrm{~b}$ & 75,3 \\
\hline & G & 90 & 0 & $2 a$ & $3 a$ & $1 \mathrm{a}$ & 5 & 11 & 12,2 & $79 \mathrm{a}$ & 87,8 \\
\hline
\end{tabular}

For each clone, means followed by the same letter in a column are not significantly different at a probability threshold of $5 \%$, according to LSD.

Treatments: $\mathrm{V}=$ in vitro plantlet; $\mathrm{G}=$ grafted plants

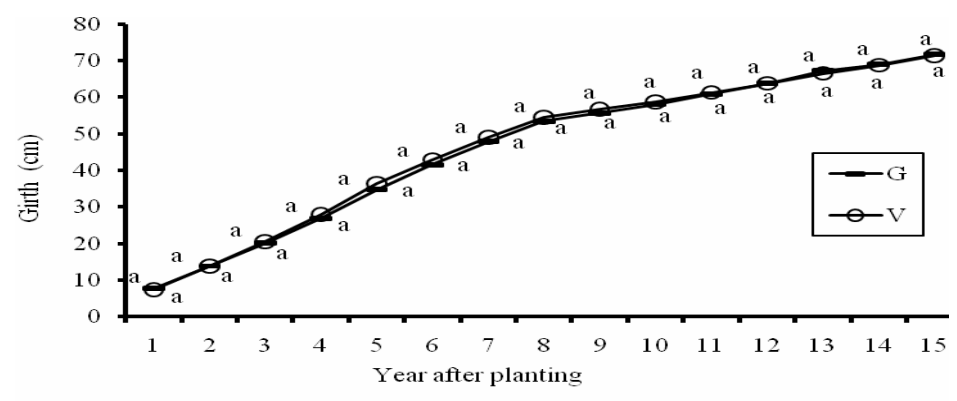

Figure 1: Girth of the trunk $1 \mathrm{~m}$ above ground of PR 107 
The girth of in vitro plantlets of RRIM 600 has been always higher than that of budded plants. Apart from the 3rd to the 7th year after planting, this superiority has generally been significant (Figure 2). The volume of in vitro plantlets has always been significantly higher than that of grafted plants except second and third years. The in vitro plantlets RRIM 600 have registered, comparing to budded plants, a gain of volume of $14.36 \%$ (Table 2).

The trunk girth of in vitro plantlets of IRCA 18 has been higher than that of grafted during all evaluated years of growth. However, this superiority was significant only for the first year after planting (Figure 3 ). The trunk volume of IRCA 18 in vitro plantlets has always been higher than that of budded plants. This superiority of the in vitro plantlets was significant from the 7 th year up to the 14th. The in vitro plantlets have recorded, compared to budded plants a volume gain of $16.83 \%$ (Table 2).

Production of dry rubber: Table 3 shows the annual dry rubber production expressed in grams per tree, and the ratio of production of in vitro plantlets by the production of budded plants.
The rubber production of an in vitro plantlet of PR 107 has been statistically identical to that of a budded plant during the first five years of taping. At the 6th and $7^{\text {th }}$ year, the production of in vitro plantlet has been significantly higher. After seven years of taping, an in vitro plantlet has produced an average of 3.5\% more rubber than a budded plant (Table 3 ).

The in vitro plantlets of IRCA 18 have shown a dry rubber production per tree higher than that of budded plants, for the nine years of taping. This superiority has been significant at the $4^{\text {th }}$ year of taping and from the $6^{\text {th }}$ to the $9^{\text {th }}$ year. An in vitro plantlets of IRCA 18 has produced an average of $8120 \mathrm{~g}$ of dry rubber per year against $6578.7 \mathrm{~g}$ for budded plant, whether a gain per tree of $23.43 \%$ (Table 3). For the RRIM 600, in vitro plantlets have showed a production per tree significantly higher than that of budded plants for all the seven years of taping. An in vitro plantlet of RRIM 600 has produced an average of $6093 \mathrm{~g}$ of dry rubber against $4603.7 \mathrm{~g}$ for budded plant, whether a gain per tree of $32.35 \%$ (Table 3 ).

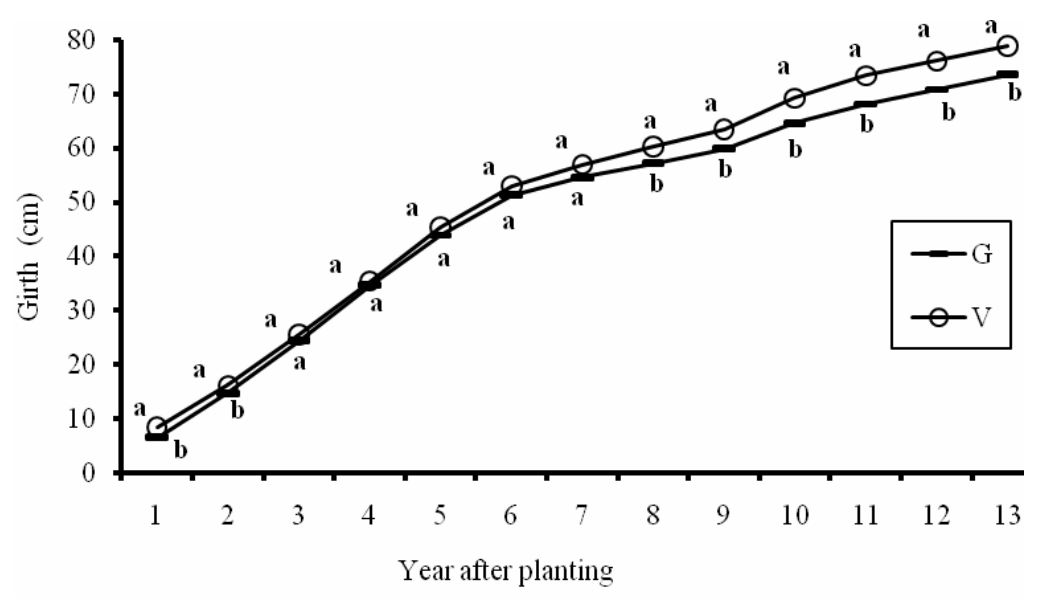

Figure 2: Girth of the trunk $1 \mathrm{~m}$ above ground of RRIM 600

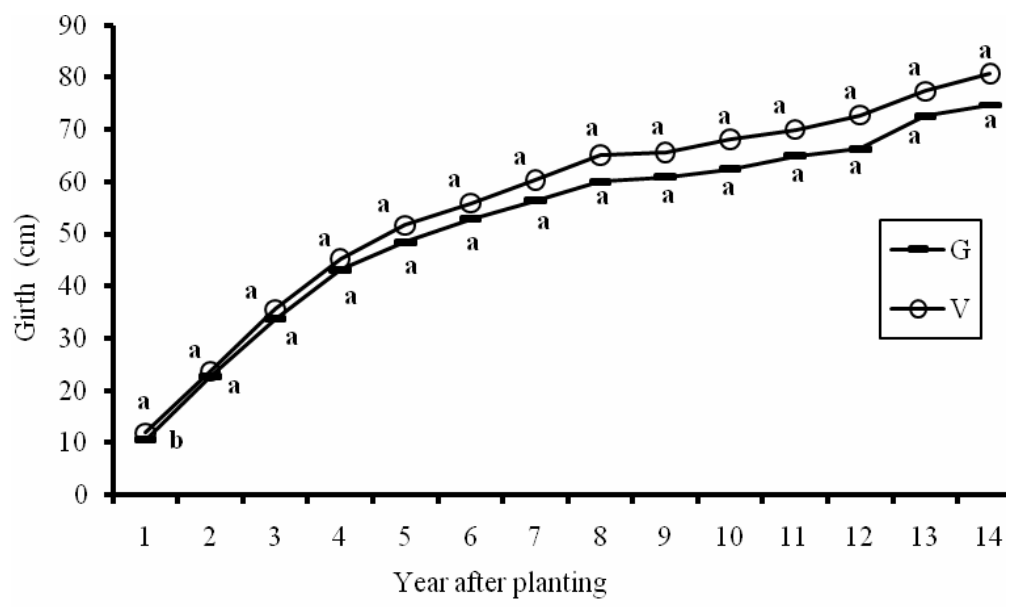

Figure 3: Girth of the trunk $1 \mathrm{~m}$ above ground of IRCA 18 
Table 2: Volume of trunk of clones PR 107, RRIM 600 and IRCA 18

\begin{tabular}{|c|c|c|c|c|c|c|}
\hline \multirow{2}{*}{$\begin{array}{c}\text { Clones } \\
\text { Year after planting }\end{array}$} & \multicolumn{2}{|c|}{ PR 107} & \multicolumn{2}{|c|}{ RRIM 600} & \multicolumn{2}{|c|}{ IRCA 18} \\
\hline & G & V & G & V & G & V \\
\hline 3 & & & 70052 b & 81206 a & & \\
\hline 4 & $91262 \mathrm{a}$ & $116333 \mathrm{a}$ & $140389 a$ & $154369 \mathrm{a}$ & $168712 \mathrm{a}$ & $188560 \mathrm{a}$ \\
\hline 5 & $154470 \mathrm{~b}$ & $182003 \mathrm{a}$ & $226452 \mathrm{a}$ & $250577 \mathrm{a}$ & 232998 a & $264832 \mathrm{a}$ \\
\hline 6 & $220823 \mathrm{a}$ & $246834 \mathrm{a}$ & $308264 \mathrm{~b}$ & $350284 \mathrm{a}$ & $304259 a$ & $346935 \mathrm{a}$ \\
\hline 7 & 299738 a & $347391 \mathrm{a}$ & $350156 \mathrm{~b}$ & 397748 a & 347929 b & $405203 \mathrm{a}$ \\
\hline 8 & $380363 \mathrm{a}$ & $420698 \mathrm{a}$ & $381667 b$ & $434282 \mathrm{a}$ & 393314 b & $471317 \mathrm{a}$ \\
\hline 9 & $410921 \mathrm{a}$ & $445255 \mathrm{a}$ & $405704 \mathrm{~b}$ & $477744 \mathrm{a}$ & $436127 \mathrm{~b}$ & $511713 a$ \\
\hline 10 & $441480 \mathrm{a}$ & $469812 \mathrm{a}$ & $469161 \mathrm{~b}$ & $550625 \mathrm{a}$ & $456804 \mathrm{~b}$ & $557997 \mathrm{a}$ \\
\hline 11 & $487350 \mathrm{a}$ & $521652 \mathrm{a}$ & $516175 b$ & $591879 a$ & $513267 \mathrm{~b}$ & $619006 \mathrm{a}$ \\
\hline 12 & $524154 a$ & $553146 \mathrm{a}$ & 551502 b & $634865 \mathrm{a}$ & 588401 b & $666797 \mathrm{a}$ \\
\hline 13 & $576694 \mathrm{a}$ & $600339 \mathrm{a}$ & $586829 \mathrm{~b}$ & $677851 \mathrm{a}$ & 652977 b & $749446 \mathrm{a}$ \\
\hline 14 & 594140 a & $603494 \mathrm{a}$ & & & 638706 b & $773912 \mathrm{a}$ \\
\hline 15 & $639466 \mathrm{a}$ & $655840 \mathrm{a}$ & & & & \\
\hline Mean & 401738 & 430233 & 364214 & 418312 & 430318 & 505065 \\
\hline VIG (\%) & \multicolumn{2}{|c|}{9.93} & \multicolumn{2}{|c|}{14,36} & \multicolumn{2}{|c|}{16,83} \\
\hline
\end{tabular}

For each clone, means followed by same letter in a line are not significantly different at a probability threshold of $5 \%$, according to LSD.

Treatments: $\mathrm{V}=$ in vitro plantlet; $\mathrm{G}=$ grafted plant

Table 3 : Annual mean of dry rubber yield expressed in gram per tree $(\mathrm{g} / \mathrm{t})$

\begin{tabular}{|c|c|c|c|c|c|c|}
\hline \multirow{2}{*}{ Year of taping } & \multicolumn{2}{|c|}{ PR 107} & \multicolumn{2}{|c|}{ RRIM 600} & \multicolumn{2}{|c|}{ IRCA 18} \\
\hline & G & V & G & V & G & V \\
\hline 1 & $1366 \mathrm{a}$ & 1276 a & 3644 b & 4156 a & 3060 a & $4692 \mathrm{a}$ \\
\hline 2 & $1736 \mathrm{a}$ & 1592 a & 4464 b & 5628 a & $4680 \mathrm{a}$ & $5256 \mathrm{a}$ \\
\hline 3 & $1214 \mathrm{a}$ & $1424 \mathrm{a}$ & $2650 \mathrm{a}$ & $2700 \mathrm{a}$ & $4284 \mathrm{a}$ & $4764 \mathrm{a}$ \\
\hline 4 & 1835 a & 1775 a & 5388 b & 7992 a & $7764 \mathrm{~b}$ & 9648 a \\
\hline 5 & 928 a & $823 \mathrm{a}$ & $4620 \mathrm{~b}$ & $6972 \mathrm{a}$ & $10320 \mathrm{a}$ & $8892 \mathrm{a}$ \\
\hline 6 & $2035 b$ & $2376 \mathrm{a}$ & 5832 b & 8088 a & $10212 b$ & $13404 \mathrm{a}$ \\
\hline 7 & $2184 b$ & $2428 \mathrm{a}$ & $5628 b$ & $7116 \mathrm{a}$ & $3576 \mathrm{~b}$ & $5076 \mathrm{a}$ \\
\hline 8 & - & - & - & - & 7668 b & $12168 \mathrm{a}$ \\
\hline 9 & - & - & - & - & $7644 \mathrm{~b}$ & $9180 \mathrm{a}$ \\
\hline Mean & 1614.0 & 1670.6 & 4603.7 & 6093.1 & 6578.7 & 8120.0 \\
\hline VIG (\%) & \multicolumn{2}{|c|}{3.51} & \multicolumn{2}{|c|}{32.35} & \multicolumn{2}{|c|}{23.43} \\
\hline
\end{tabular}

For each clone, means followed by the same letter in a line are not significantly different at a probability threshold of $5 \%$, according to LSD.

Treatments: $V=$ in vitro plantlet; $G$ = grafted plants

Table 4: Annual mean yield in kilogram per hectare (kg/ha)

\begin{tabular}{|c|c|c|c|c|c|c|}
\hline \multirow{2}{*}{} & \multicolumn{2}{|c|}{ PR 107 } & \multicolumn{2}{c|}{ RRIM 600 } & \multicolumn{2}{c|}{ IRCA 18 } \\
\cline { 2 - 7 } & G & V & G & V & G & V \\
\hline Yield (kg/ha) & 631.1 & 738.4 & 2191.4 & 2555.0 & 2945.0 & 3117.5 \\
\hline VIG (\%) & \multicolumn{2}{|c|}{$\mathbf{1 7 , 0 1}$} & \multicolumn{2}{|c|}{$\mathbf{1 6 . 6 0}$} & $\mathbf{5 . 8 6}$ \\
\hline
\end{tabular}


Table 4 shows the annual yield in kilogram per hectare $(\mathrm{kg} / \mathrm{ha})$ and the ratio of the yield of in vitro plantlets onto the yield of budded plants. This yield $(\mathrm{kg} / \mathrm{ha})$ has been strongly affected by population density of usable trees. For all studied clones, the in vitro plantlets have recorded higher yield per hectare than budded plants. Gains in yield per hectare of $17 \%, 16.6 \%$ and $5.86 \%$ were respectively obtained with in vitro plantlets of PR 107, RRIM 600 and IRCA 18 (Table 3).

Physiological profile: Figures 4, 5, 6 and 7 show the average during tapping years of dry rubber (DRC), sucrose (Suc), inorganic phosphorus (Pi) and thiols (RSH) contents.

Dry rubber content (DRC): The rate of dry rubber has varied according to the clone. It was higher for IRCA 18 than IRCA 18 and PR 107. Inside the clone, this rate has not varied according to the multiplication mode. In vitro plantlets and budded plants showed statistically, the same rate of dry rubber.
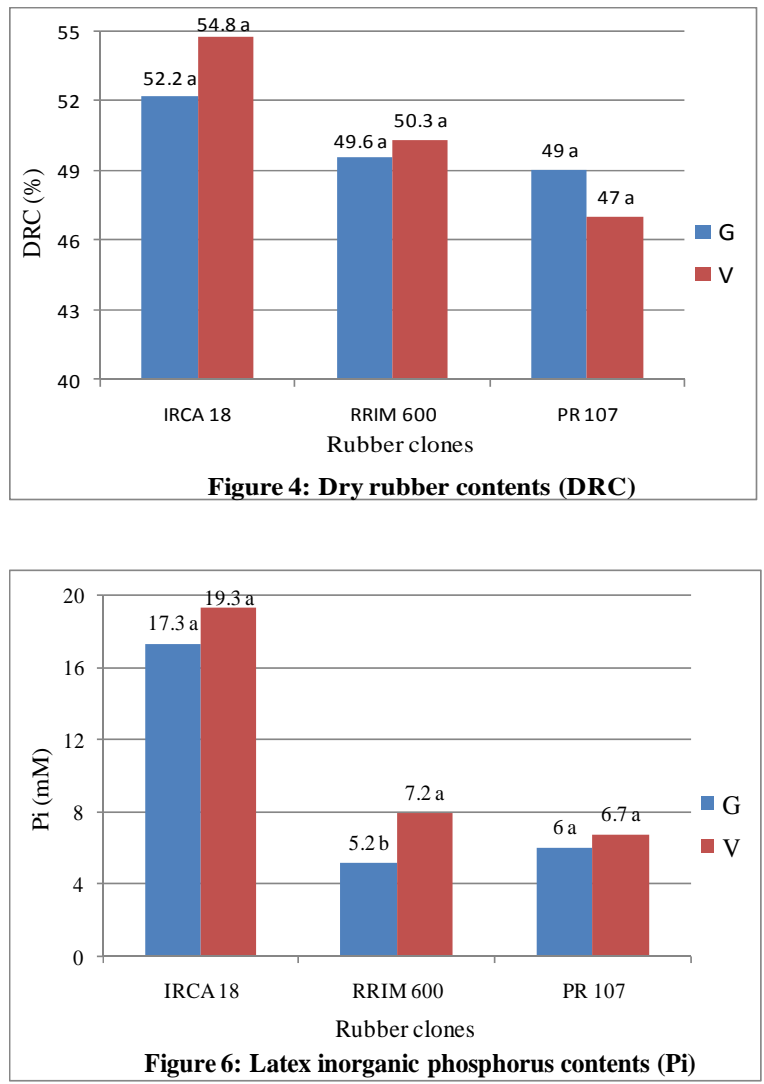

Latex sucrose content (Suc): RRIM 600 has revealed the higher sucrose content. For IRCA 18, the grafted plants have registered a sucrose content significantly higher in vitro plantlets. Both in vitro plantlets and grafted showed the same sucrose content for the clones RRIM 600 and PR 107.

Latex inorganic phosphorus content (Pi): The content of inorganique phosphorus has been higher for IRCA 18, then come that of RRIM 600 and PR 107 at the end. For IRCA 18 and PR 107, the rate of $\mathrm{Pi}$ has been statistically equal for the two mode of propagation. In vitro plantlets have showed significantly the higher Pi content for RRIM 600.

Latex thiol contents (RSH): For all clones, the thiols contents was less variables. Both in vitro plantlets and grafted showed the same sucrose rate for the clone PR 107. Grafted plants showed significantly the higher thiols content for RRIM 600. Concerning the RRIM 600, the in vitro plantlets revealed the higher thiols content.
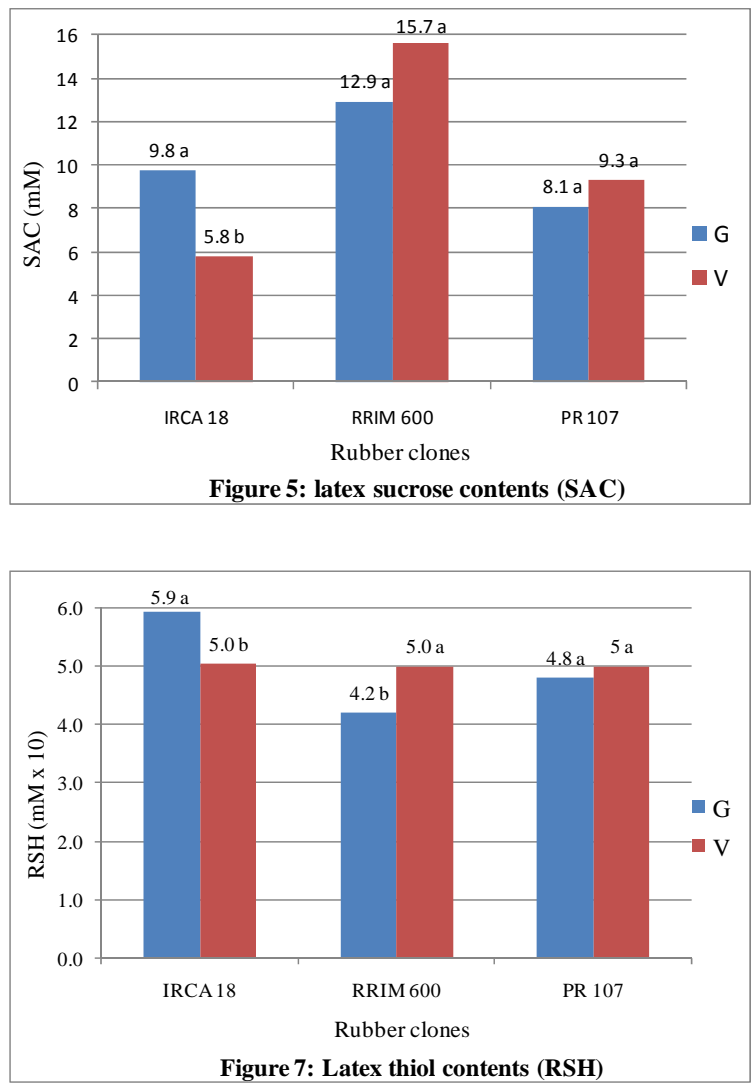


\section{DISCUSSION}

The rate of exploitable in vitro plantlets compared to budded plants has been variable. It was strongly influenced by several causes including mortality, breakage due to wind and stunting. The low density of usable in vitro plantlets of IRCA18 is linked to the mortality due to a hearth of Fomes and other causes such as breakage due to wind. However, the in vitro plantlets of this clone showed no significant sensitivity to the breakage of trees. The occurrence of breakage was not related to the mode of propagation but rather to clone IRCA 18 , which is susceptible to the breakage (Clement et al., 2007). With the PR 107, it is the combined effect of mortality and growth retardation that resulted in the low rate of usable budded plants.

Analysis of the results shows that the use of in vitro plantlet has permitted a gain in volume and girth of the trunk as it has been already shown by Carron et al.(1997) on clones PB 260 and IRCA 18 and by Dibi (2004) on PB 260. A gain in girth of $6 \%$ with in vitro plantlet has been reported by Carron et al in 2003 with clone IRCA 18. Similar good growth of in vitro plantlets have been obtained with the apple (Embree and Hicks, 1985; Larsen and Higgins, 1990). With eucalyptus and teck, the highest initial growth of in vitro plantlets has gradually disappeared, 2 or 3 years after planting (Mascarenhas et al., 1988). Equivalent or less growth of in vitro plantlets to that of a control has been observed with Pinus radiata, Pinus taeda, peach, cherry and prunus (Frampton and Isik, 1987; Navatel and Bourrain, 1989; Bonga and Aderkas, 1992 ). The gain in girth of in vitro plantlet has been influenced by the metabolic class of the clone. It has increased from the low metabolism clone (PR 107) to the high one.

The recorded data of in vitro plantlets in this study are the first assembling from 7 to 9 years of production in fields. They allow to say that the in vitro plantlet produce more rubber than budded plant of the same rubber clone. An in vitro plantlet permits to record a gain of dry rubber production from $3 \%$ to $32 \%$ per tree. These results are in accordance with a gain of production of $16 \%$ obtained by Dibi (2004) with in vitro plantlets of rubber clone PB 260. Carron and al in 2003 have recorded two years of production with a gain of $20 \%$ obtained with in vitro plantlets of IRCA 18. The estimated yield per hectare has been strongly influenced by the density of harvestable trees. Gains have varied from 5.86\% for IRCA 18 with a low density of usable in vitro plantlet to $17 \%$ for the PR 107. This result reveals the impact that a small difference in usable tree density may have on yield spreads.

The overall biosynthetic laticiferous activity observed through the rate of dry rubber (Gohet, 1996) was generally identic for all the treatments. This shows that the tissue culture has not significant effect on the biosynthetic lactiferous activities of clones PR 107, RRIM 600 and IRCA 18. The sucrose content is the principal substrate for rubber synthesis. The lower sucrose contents of in vitro plantlets for IRCA 18 shows a less supply of the laticiferous or higher consumption of sucrose for more rubber production (Compagnon, 1986). Seeing the higher rubber production of the in vitro plantlet of IRCA 18, we can assume that the low level of sucrose is due to the high activation of rubber production. The RRIM 600 in vitro plantlets show strong lactiferous metabolism than budded plants. In fact the low Pi content of RRIM 600 budded plants is due to a weak activation of the energetic metabolism of the laticiferous (Jacob et al., 1988). The good levels of rubber production noted with in vitro plantlets of RRIM 600 corroborate this. Higher thiols content of in vitro plantlets compared to those of budded plants indicates more enzyme availability assuring colloidal stability during the isoprenic synthesis process.

We notice that the physiological profile of in vitro plantlet varied according to the metabolism class of the clone to which it belongs. For the PR 107 of low metabolism, in vitro plantlets showed identical profile with grafted plants. With RRIM 600 a medium metabolism clone, in vitro plantlets showed higher energetic metabolism of the laticiferous (Pi) (RSH). The in vitro plantlets of IRCA 18 a high metabolism clone have low sucrose content which indicate less amount of sucrose supply than it consumption for rubber production. They also showed lower colloidal stability. That is why in vitro plantlets of IRCA 18 showed less gain in dry rubber production than those of RRIM 600.

Thus the gain in production of dry rubber per tree of in vitro plantlets has been influenced by the metabolic class and the physiological profile of the clone.

\section{CONCLUSION}

The study in fields of in vitro plantlet of rubber of clones PR 107, RRIM 600 and IRCA 18 has permitted to register some assets and especially to obtain scientific data on this new type of material in rubber cultivation.

The survival rate of in vitro plantlets transfer to field has varied according to experimental plot. This rate has been strongly influenced by many causes including: mortality, damage due to wind, stunting. Juvenility 
induced by in vitro culture has permitted to record a gain of volume of trunk from 9 to $16 \%$. We can say that the in vitro plantlet produce more rubber than budded plant of the same rubber clone. An in vitro plantlet tree has permitted to record a gain of dry rubber production of 3 to $23 \%$. Therefore the gain in girth of in vitro plantlet has been influenced by the metabolic class of the clone. The gain in dry rubber production per tree of in vitro plantlets has been also influenced by the metabolic class and the physiological profile of the clone. The physiological profile of in vitro plantlet varied according to the metabolism class of the clone to which it belongs. In light of these results, the use of in vitro plantlet as planting material could be considered to increase the productivity of rubber plantations.

\section{ACKNOWLEDGEMENTS}

The authors thank the management of Côte d'Ivoire National Agronomique Research Center (CNRA) for allowing this study and for its sponsorship. They also thank CIRAD for production and supply of in vitro plantlets. The authors are greatly indebted to the CNRA research technicians of the Rubber Program for their assistance in the field operations.

(1) CIRAD: International Cooperation Center of Agronomic Research for Development (France)

(2) CNRA: National Center of Agronomic Research (Côte d'Ivoire)

\section{REFERENCES}

Anonymous 1 (1993). Recueil de fiches de clones Hevea. CIRAD-Cultures Pérennes, ed., Montpellier, France, pp. 20.

Bonga, J.M. and Aderkas, V.P. (1992). In vitro cultured of trees. Forestry Sciences, 38, pp. 236.

Carron, M.P. (1982). L'embryogenèse somatique de l' Hevea brasiliensis (KUNTH) MULL-ARG: une technique de multiplication végétative au service de l'amélioration génétique. Thèse de l'Université des Sciences et Techniques du Languedoc, pp. 167.

Carron, M.P. and Enjalric, F. (1983). Perspectives du microbouturage de l'Hevea brasiliensis. Caoutchoucs et Plastiques, 627/628, pp 65-68.

Carron, M.P., Enjalric, F., Lardet, L. and Deschamps, A. (1989). Rubber (Hevea brasiliensis Müll. Arg.) in Y.P.S. Bajaj. Ed. Biotechnology in agriculture and forestry. Vol. 5. Trees II. Springer Verlag. Berlin (Allemagne), pp. 222245.

Carron, M. P., Dea, B.G., Tison, J., Leconte, A. and Keli, J. (1997). Croissance en champ de clones d'Hevea brasiliensis issus de culture in vitro. Plantation Recherche Développement, 4 (4), pp. 264-270.

Carron, M.P., Ludovic, L. and Dea B.G. (1998). Micropropagation de l'hévéa par embryogenèse somatique. Plantation Recherche Développement, 5 (3), pp 187-194.

Carron, M.P., Lardet, L., Leconte, A., Boko, C., Dea, G.B. and Keli, J. (2003). Field growth and rubber yield of Hevea brasiliensis (Muëll.-Arg.) from budded versus in vitro micropropagated plants from clone IRCA 18. In : Economou A.S. (ed.), Read P.E. (ed.). Proceedings of the First International Symposium on acclimatization and establishment of micropropagated plants, Sani-Halkidiki, Macedonia, Greece, 19-22 September, 2001. Wageningen : ISHS, pp. 283-293.

Clement, D.A., Priyadarshan, P.M., Tran, T.T.H. and Venkatachalam, P. (2007). Hevea rubber breeding and genetics. Plant breeding reviews. John Wiley \& Sons Inc (eds). Volume 29, Chapter 4, pp. 177-283.

Combe, J.C. and Du Plessix, C.J. (1971). Variabilité intraclonale et développement de l'hévéa. Rapport de recherche IRCA SA 3/71, pp. 53.

Compagnon, P. (1986). Le caoutchouc naturel. Coste R.. ed. G.P. Maisonneuve et Larose, Paris, pp. 595.

Dibi, K. (2004). Evaluation des performances agronomiques de somaplants du clone PB260 d'Hevea brasiliensis Muel. Arg. Mémoire de DEA de Physiologie Végétale, option: Agrophysiologie, Université de Cocody, Abidjan, Côte d'Ivoire, pp. 56.

Dijkman, M.J. (1951). Hevea - Thirty years of research in the Far East. University of Miami Press U.S.A., Coral Gables, Florida, pp. 329.

Embree, C.G. and Hicks, G.S. (1985). Field performance and micropropagation of a hardly apple rootstock candidate KCS-3. Can. J. Plant Sci., 65, pp. 459-464.

Frampton, L.J. and Isik, K. (1987). Comparison of field growth among loblolly pine seedlings and three plant types produced in vitro. Tech. Assoc. Pulp Pap. Ind., J., 7, pp. 119-123.

Gohet, E. (1996). La production de latex par Hevea brasiliensis. Relation avec la croissance. Influence de différents facteurs: origine clonale, stimulation hormonale, réserves hydrocarbonées. Thèse de Doctorat, Université des Sciences et Techniques du Languedoc, Montpellier II, France, pp. 343.

Jacob, J.L., Serres, E., Prévôt, J.C., Lacrotte, R., Vidal, A., Eschbach, J.M. and d'Auzac J. (1988). Mise au point du diagnostic latex. Agritrop, 12, pp. 97-118.

Lardet, L., Bes, M., Enjalric, F. and Carron, M.P. (1994). Mineral imbalance in Hevea brasiliensis microcuttings: relation with in vitro multiplication and acclimatization. $\mathrm{J}$. Plant Nutrit. 17(12), 2135-2150.

Larsen, F.E. and Higgins, S. (1990). Early field performance of several self-rooted, micropropagated apple cultivars vs. trees on seedling or M. 7a rootstocks. Fruit Var. J., 44, pp. 185-192.

Le Roux, Y. (1994). Mise en place de l'architecture racinaire d'Hevea brasiliensis. Etude comparée du semis et de la microbouture. Thèse de doctorat, Université d'AixMarseille II, F. pp. 295

Mascarenhas, A.F., Khuspe, S.S., Nadgauda, R.S., Gupta, P.K. and Khan B.M. (1988). Potential of celll cuture in plantation forestry programs. In: Genetic manipulation of woody plants, J.W. Hanower et D.e. Keatley éd.(New York), pp. 391-142.

Navatel, J.C. and Bourrain, L. (1989). Micropropagation et arbres fruitiers. Infos-CTIFL, 51, pp. 6-10. 